\title{
Integrated Disease Management Capsule for Wilt/Root Rot Complex of Chili
}

\author{
Waseem Ali Dar*, Mir Gh. Hassan, Pervaiz Ahmad Sheikh, \\ Baby Summuna and Shabir Ahmad Ganaie
}

\author{
Division of Plant Pathology, S. K. University of Agricultural Sciences and Technology of \\ Kashmir, Shalimar, Srinagar-190025, Jammu and Kashmir, India
}

*Corresponding author

\begin{tabular}{|l|}
\hline Ke y w or d s \\
$\begin{array}{l}\text { Disease } \\
\text { management } \\
\text { capsule, Chili }\end{array}$ \\
\hline Article Info \\
\hline $\begin{array}{l}\text { Accepted: } \\
\text { 12 December } 2017 \\
\text { Available Online: } \\
\text { 10 January } 2018\end{array}$ \\
\hline
\end{tabular}

\section{A B S T R A C T}

The present investigation was conducted to assess the wilt/root rot incidence in chilli (Capsicum annum) in Kashmir and to examine management practices. Survey was carried out in three districts of Kashmir viz., Ganderbal, Baramullah and Pulwama during 2016. Damping-off and wilt/root rot incidence in the districts varied from 7-34 and 11-52\% respectively with maximum in disease incidence in district in Ganderbal and minimum in Pulwama. The pathogens responsible for wilt/root rot are Fusarium pallidoroseum, F. oxysporum, F. solani, Phytophthora capsici, $R$. solani and Sclerotium rolfsii and Pythium sp. was observed to be incitant of damping-off. Wilt/root rot and damping-off being soil borne, the primary infections are needed to be controlled with suitable fungicides. Field experiments were conducted to study the disease control with different fungicides alone or in combination with bioagents. The results indicated that minimum wilt/root rot incidence $(7.0 \%)$ and maximum dry fruit yield $74.73 \mathrm{q} / \mathrm{ha}$ was recorded in treatment combination of carbendazim (seed treatment) + metalaxyl (seedling dip) + hexaconazole (foliar spray) as compared to other possible combinations and their individual treatments. Wilt/root rot and dry fruit yield of chilli was investigated in response to various levels of organic amendments (FYM 20, 30 and $40 \mathrm{t} / \mathrm{ha}$ and vermicompost 10, 15 and $20 \mathrm{t} / \mathrm{ha}$ ) alone and in combination with the recommended nitrogen fertilizer dose (RFD). Also, the impact of split doses of fertilizer application 60:60, 60:30:30, 40:40:40 and 80:40 on wilt/root rot complex was assessed. Vermicompost $20 \mathrm{q} / \mathrm{ha}+\mathrm{RFD}$ was most effective in reducing the wilt/root rot incidence up to $(21.0 \%)$ and increased dry fruit yield of chilli $(55.10 \mathrm{q} / \mathrm{ha})$ when compared to control.

\section{Introduction}

Chilli (Capsicum annum L.) is an important cash crop grown under both tropical and subtropical conditions. It is mainly cultivated for its green fruits and for the dry chilli as the spice of commerce. It is rich source of vitamin $\mathrm{C}, \mathrm{A}$ and the green fruits also contain vitamin
$\mathrm{P}$ (rutin) in appreciable proportion (Muthkrishnan et al., 2002). India produces 1.446 million tones of ripe dry chillies with an area of 0.869 million ha under its cultivation (Muthukumar et al., 2010; Anonymous, 2013). In Jammu and Kashmir State, chilli is grown on an area of 3280 ha with annual production of 6480 metric tons (Anonymous 
2010). Chilli crop is attacked by many biotic and abiotic nature leading to great loss to cultivars up to $12-15 \%$ in India (Bagri et al., 2004; Sharma et al., 2005). Several Fusarium species viz., F. oxysporum and F. solani have been reported as the major pathogens causing wilt disease in solanaceous crops in Gujarat and Uttar Pradesh (Yelmame et al., 2010, Dwivedi and Enespa, 2013). Fusarium root rot has become an important and widespread disease of cucurbits and solanaceous vegetables in many countries worldwide (Vakalounakis and Chalkias, 2004). Other pathogens from different genera including Phytophthora, Pythium and Rhizoctonia have been found associated with infections on roots and stems (Vatchev, 2007). Vermicompost improves the soil physical, chemical and biological properties along with conserving the moisture holding capacity of soil (Premsekhar and Rajashree, 2009) and also resolves the deficiency of organic matter in soils (Alam et al., 2007). Vermicompost protects plants against various pests and soil borne pathogens by suppressing or repelling or by inducing biological resistance or by killing them through pesticidal action (Sinha et al., 2010). Fertilizer is one of the major factor of crop production and nitrogen is very much essential for good plant establishment and growth while potassium is needed for good fruit yield (Uddin and Khalequzzaman, 2003).

\section{Materials and Methods}

\section{Isolation, characterization identification of pathogenic fungi}

and

The wilt/root rot fungi isolated from the chilli by standard isolation method under aseptic conditions. The infected tissues of the chilli plants were cut into small pieces of $2-5 \mathrm{~mm}$ size, surface sterilized and placed in petri plates containing sterilized PDA and incubated at $28 \pm 1^{\circ} \mathrm{C}$. Outgrowing hyphal tips were sub-cultured to develop a purified culture
(Dasgopta, 1988). The isolated fungi were studied for their colony characters, mycelial growth and pigmentation. Morphological characterization of isolated fungi viz., shape, size and septation of mycelium and spores were recorded. The characteristics observed were compared with authentic descriptions of Nelson et al., (1983) and Sneh et al., (1998). Pathogenicity was established by following Koch's postulates. The disease incidence in nursery/fields was assessed as per the method of Johnston and Both (1983).

Disease incidence $(\%)=$ No. of infected plants

Total number of units assessed

\section{Field experiments}

\section{Effect of different methods of fungicide/BCA application on wilt/root rot complex in chilli}

To study the effect of seed treatment + soil drench, seed treatment + seedling dip and seed treatment + seedling dip + foliar sprays against wilt/root rot complex, field experiments was laid out at Khanbal, Pulwama, Kashmir. Well pulverized plots of 2 $\mathrm{m} \times 2 \mathrm{~m}$ were prepared. The seeds of chilli cv. 'Kashmir Long - 1' procured from the Division of Vegetable Sciences, SKUAST-K were treated with fungicides (captan or carbendazim or hexaconazol or metalaxyl) or bio-agent ( $T$. harzianum), as per treatment and were sown in first week of April. Forty-five day old seedlings were uprooted and subjected to seedling dip as per treatment before transplantation to field. In some treatments soil was drenched with selected fungicides as per treatment details given in Table 2. Four sprays of selected fungicides were given at 15 days interval no sooner the initial wilt symptoms appeared. The fungicides were procured from the division of Plant Pathology SKUAST-K, Shalimar, Kashmir. The 
observation on wilt/root rot incidence and dry fruit yield of chilli was recorded in each treatment at harvest.

\section{Effect of recommended fertilizer dose (RFD), FYM and vermicompost on wilt/root rot complex disease of chilli}

A field experiment was conducted at PohruPeth, Handwara, Kupwara in 2016 on chillie cv. Kashmir Long -1 ' seeds procured from the Division of Vegetable Sciences, SKUAST$\mathrm{K}$ to assess the impact of various levels of organic amendments (FYM and vermicompost) alone and in combination with the recommended nitrogen fertilizer dose (RFD). Also, the impact of split fertilizers application on wilt/root rot complex was assessed. For this, the field was well pulverized and plots of $2 \mathrm{~m} \times 2 \mathrm{~m}$ size prepared.

Treatments comprised of 3 levels of well decomposed farm yard manure [FYM] $(20,30$ and $40 \mathrm{t} / \mathrm{ha}$ ) and vermicompost (10, 15 and 20 t/ha) and combined application of FYM and vermicompost along with recommended nitrogen fertilizer dose $(120 \mathrm{~kg} \mathrm{~N} / \mathrm{ha})$. The other treatments included split doses of nitrogen fertilizer application viz., 60:60, 60:30:30, 40:40:40 and 80:40 including FYM (a) 20 t/ha. An untreated control was also maintained. The FYM and vermicompost was incorporated into the soil 15 days prior to the seedling transplantation. The nitrogen fertilizer in split dose treatments, as per the treatment, was applied in the form of urea either as basal dose and/or one and two months after seedling transplantation. The phosphorus and potassium fertilizers were applied in all the treatments uniformly at recommended dose. The experiment was conducted in a completely randomized block design with all the treatments replicated three times. The recommended package of practices was followed, except for nitrogen fertilizer and disease control. The disease incidence was recorded 90 days after seedling transplantation and dry fruit yield was recorded at harvest (Table 3).

\section{Results and Discussion}

During the period 2014-16, a total of 116 villages in Kashmir valley viz., 56 villages (3 blocks) from Ganderbal, 27 villages (4 blocks) from Baramulla, 33 villages (3 blocks) from Kupwara, were surveyed. In all the surveyed villages chilli/capsicum nurseries/field crops were found affected by several pathogens. Highest wilt/root rot and damping-off disease incidences were observed in Ganderbal district followed by Baramulla and Kupwara districts (Table 1). In district Ganderbal the wilt/root rot incidence range was 15-52, 17-35 and 31$42 \%$ in Kangan, Soura and Ganderbal blocks, respectively, with maximum incidence in Kangan block.

In Ganderbal district, block Kangan showed highest damping-off incidence (25\%). The damping-off ranged from 10-32, 15-35 and 9$25 \%$ in Kangan, Soura and Ganderbal blocks, respectively. In district Baramulla the wilt/root rot incidence range was 9-20, 14-26, 11-23 and $16-27 \%$ in Sopore, Dangerpora, Pattan and Tangmarg blocks, respectively, with maximum incidence in Dangerpora block. Damping-off was in the range of 7-28, 11-22, 15-24 and 12-21\% in Sopore, Dangerpora, Pattan and Tangmarg blocks, respectively. In district Kupwara, the wilt/root rot and damping-off incidence range was 17-31, 1435, 14-38 and 8-30, 11-36, 8-29, respectively, in Langate, Rajawara and Ramhal blocks. The lack of availability of treated seeds, excessive irrigation, and improper crop management practices assumed as the reasons for high wilt/root rot incidence in Ganderba. The practice of monocropping in vegetables may also be one of the factors for high wilt/root rot and damping-off in Kashmir valley. These 
assumptions are substantiated by the findings of Najar and Ahmad (2012) who attributed higher wilt/root rot incidence in vegetables to monocropping while McGee (1992) attributed it to the use of untreated seeds in North West Pacific. Frequent irrigation and excessive use of fertilizers are reported to be amongst the important predisposing factors for the perpetuation of pathogens in Uttrakhand and Jammu and Kashmir States (Mamta et al., 2012, Najar and Ahmad 2012).

\section{Effect of different methods of fungicide/BCA application on wilt/root rot disease of chilli under field conditions}

All the treatments applied either individually or in combination, were found significantly effective in minimizing wilt/root rot disease as compared to check (Table 2). Minimum wilt/root rot incidence $(7.0 \%)$ was observed in treatment combination of carbendazim (as seed treatment, ST) + hexaconazole (as seedling dip, SD) + metalaxyl (as foliar spray, FP); followed by $7.5 \%$ disease incidence in treatment combination of carbendazim (ST) + metalaxyl (SD) + hexaconazole (FP), $9.25 \%$ disease incidence in $T$. harzianum (ST) + metalaxyl (SD) + hexaconazole (FP) and 9.75\% disease incidence in captan (ST) + metalaxyl (SD) + hexaconazole combination.

The untreated control showed disease incidence of $48.3 \%$. Maximum dry fruit yield of $74.73 \mathrm{q} / \mathrm{ha}$ was observed in treatment combination of carbendazim (ST) + hexaconazole (SD) + metalaxyl (FP) followed by $73.93 \mathrm{q} / \mathrm{ha}$ in treatment combination of carbendazim (ST) + metalaxyl (SD) + hexaconazole (FP); $70.0 \mathrm{q} /$ ha in $T$. harzianum $(\mathrm{ST})+$ metalaxyl $(\mathrm{SD})+$ hexaconazole $(\mathrm{FP})$ and $68.9 \mathrm{q} / \mathrm{ha}$ in captan (ST) + metalaxyl (SD) + hexaconazole (FP) combination as compared to $32.6 \mathrm{q} / \mathrm{ha}$ in case of check. Our findings are in agreement with (Madhuri and Gayathri, 2014) who reported that integration of different treatments drenching with mancozeb, seedling dip with carbendazim, addition of vermicompost and $T$. harzainum were found effective in managing the chilli root rot in comparison with individual treatments. Present findings are in conformity with Zagade et al., (2013) who reported that seed dressing with metalaxyl and seedling dip with $T$. hamatum significantly reduced chilli wilt incidence $(8.3 \%)$ as compared to their individual treatments $11 \%$ and $15 \%$, respectively.

These results are in conformity with the report of (Madhavi and Bhattiprolu, 2011) who recorded $7.0 \%$ root rot incidence of chilli by incorporating seedling dip with carbendazim, soil drenching with dithane M-45 + vermicompost and Foliar spray of Trichoderma viride. Our findings are in agreement with Nel et al., (2007), Tarekegen et al., (2007) who reported that seed treatment and soil drenching with benzimidazoles have been shown to reduce infection by Fusarium oxysporum on various host plants. Gopinath et al., (2006) recorded that application of propiconazole $(0.05 \%)$, difenoconazole $(0.05 \%)$ and carbendazim $(0.1 \%)$ increased the yield of chilli fruits by $86 \%, 63 \%$ and $60 \%$ respectively.

While working on tomato Saini et al., (2005) reported $19.0 \%$ root rot incidence by incorporating combination of carboxin+ $\mathrm{FYM}+T$. harzianum. The present findings are in agreement with the earlier reports, integration of disease management practices are most effective in controlling Fusarial wilt in gladiolus (Suneel Anand and Harender Raj Gautum, 2006), collar and root rot in strawberry (Bhardwaj and Gautum, 2004) and soil borne diseases in vegetable nurseries (Steven et al., 2003). 
Table.1 Wilt/root rot and damping-off disease status and pathogens observed in chilli/ capsicum crops in surveyed districts of Kashmir valley (during 2014-16)

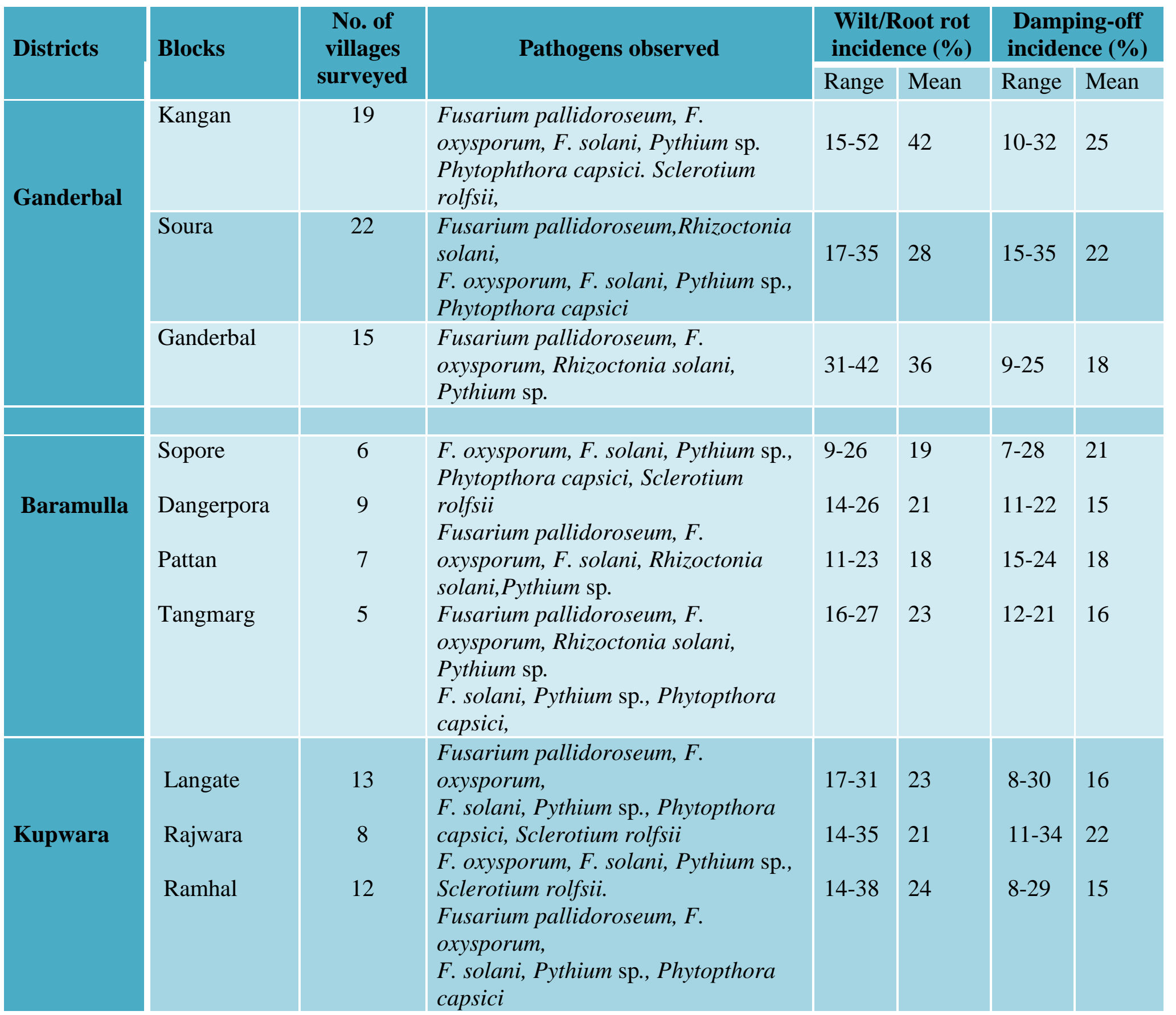


Table.2 Effect of different methods of fungicide and BCA application on wilt/root rot complex and dry fruit yield of chilli under field condition

\begin{tabular}{l} 
Treatments \\
\hline Seed treatment + Soil drench \\
Captan @ $2 \mathrm{~g} / \mathrm{kg}$ seed \\
Carbendazim @ $2 \mathrm{~g} / \mathrm{kg}$ seed \\
\hline Hexaconazole @ $2 \mathrm{ml} / \mathrm{kg}$ seed \\
Trichoderma harzianum soil drench @ $0.16 \mathrm{t} / \mathrm{ha}$ \\
\hline Seed treatment + Seedling dip \\
\hline Captan @ $2 \mathrm{~g} / \mathrm{kg}$ seed and root dip for $1 \mathrm{~h} @ 0.1 \%$ \\
\hline Carbendazim @ $2 \mathrm{~g} / \mathrm{kg}$ seed and root dip for $1 \mathrm{~h} @ 0.1 \%$ \\
\hline Hexaconazole @ $2 \mathrm{ml} / \mathrm{kg}$ seed and root dip for 1h @ 0.1\% \\
\hline Metalaxyl @ 2ml/kg seed and root for 1h @ 0.1\% \\
\hline T. harzianum soil drench @ 0.16t/ha \\
\hline Seed treatment (ST) + Seedling dip (SD) + Foliar spray (FP) \\
\hline Captan (ST) + hexaconazole (SD) + metalaxyl (FP) \\
\hline Captan (ST) + metalaxyl (SD) + hexaconazole (FP) \\
\hline Captan (ST) + hexaconazole (SD) + T. harzianum (FP) \\
\hline Carbendazim (ST) + hexaconazole (SD) + metalaxyl (FP) \\
\hline Carbendazim (ST) + metalaxyl (SD) + hexaconazole (FP) \\
\hline Carbendazim (ST) + metalaxyl (SD) + T. harzainum (FP) \\
\hline T. harzianum (ST) + captan (SD) + metalaxyl (FP) \\
\hline T. harzianum (ST) + metalaxyl (SD) + hexaconazole (FP) \\
\hline T. harzianum (ST) + T. harzinum (SD) + carbendazim (FP) \\
\hline Control \\
\hline C.D at 5\% level \\
\hline
\end{tabular}

\begin{tabular}{|c|c|}
\hline Wilt/root rot incidence (\%) & Yield (q/ha) \\
\hline & \\
\hline $28.00(31.94)^{\mathrm{gh}}$ & 49.00 \\
\hline $20.92(27.21)^{\mathrm{de}}$ & 56.08 \\
\hline $22.83(28.54)^{\mathrm{ef}}$ & 50.20 \\
\hline $27.78(31.80)^{\mathrm{gh}}$ & 48.78 \\
\hline & \\
\hline $30.77(33.68)^{\mathrm{h}}$ & 46.09 \\
\hline $10.50(18.90)^{\mathrm{a}}$ & 68.47 \\
\hline $11.75(20.04)^{\mathrm{a}}$ & 67.08 \\
\hline $15.01(22.79)^{\mathrm{g}}$ & 63.28 \\
\hline $25.69(30.45)^{\mathrm{fg}}$ & 61.01 \\
\hline & \\
\hline $10.00(18.34)^{\mathrm{a}}$ & 68.90 \\
\hline $9.75(80.90)^{\mathrm{h}}$ & 69.39 \\
\hline $13.25(22.46)^{\mathrm{bc}}$ & 65.88 \\
\hline $7.00(56.78)^{\mathrm{j}}$ & 74.73 \\
\hline $7.50(60.0)^{\mathrm{k}}$ & 73.93 \\
\hline $10.33(19.66)^{\mathrm{a}}$ & 68.98 \\
\hline $11.75(20.04)^{\mathrm{ab}}$ & 66.89 \\
\hline $9.25(74.10)^{\mathrm{l}}$ & 70.00 \\
\hline $16.67(24.09)^{\mathrm{cd}}$ & 62.01 \\
\hline $48.33(44.04)^{\mathrm{i}}$ & 32.67 \\
\hline 2.00 & 2.67 \\
\hline
\end{tabular}

Table.3 Effect of recommended doses of fertilizer different levels of FYM, vermicompost and split doses of nitrogen on wilt complex disease of chilli under field conditions

\begin{tabular}{|l|}
\hline Treatments \\
\hline FYM @ 20 q/ha + RFD \\
\hline FYM @ 30 q/ha + RFD \\
\hline FYM @ 40 q/ha + RFD \\
\hline Vermicompost 10 q/ha + RFD \\
\hline Vermicompost 15 q/ha + RFD \\
\hline Vermicompost 20 q/ha + RFD \\
\hline Vermicompost 5 q/ha + FYM 10 q/ha + RFD \\
\hline Vermicompost 7.5 q/ha + FYM 15 q/ha + RFD \\
\hline Vermicompost 10 q/ha + FYM 20 q/ha + RFD \\
\hline Split N application 60: 60 + FYM 20 q/ha \\
\hline Split N 60:30:30 + FYM 20 q/ha \\
\hline Split N 40:40:40 + FYM 20q/ha \\
\hline Split N 80: 40 + FYM 20 q/ha \\
\hline Control \\
\hline C.D at 5\% level \\
\hline
\end{tabular}

\begin{tabular}{|c|c|}
\hline Wilt/root rot incidence (\%) & Yield (q/ha) \\
\hline $28.00(31.46)^{\mathrm{de}}$ & $49.01(44.43)^{\mathrm{c}}$ \\
\hline $22.92(28.59)^{\mathrm{abc}}$ & $52.70(46.54)^{\mathrm{abc}}$ \\
\hline $20.83(27.24)^{\mathrm{ab}}$ & $56.00(48.44)^{\mathrm{a}}$ \\
\hline $28.70(32.75)^{\mathrm{def}}$ & $48.11(43.91)^{\mathrm{cde}}$ \\
\hline $25.00(29.99)^{\mathrm{bcd}}$ & $53.89(47.23)^{\mathrm{ab}}$ \\
\hline $21.00(26.22)^{\mathrm{a}}$ & $55.10(47.52)^{\mathrm{ab}}$ \\
\hline $29.17(32.68)^{\mathrm{def}}$ & $48.69(44.24)^{\mathrm{cd}}$ \\
\hline $28.25(32.10)^{\mathrm{de}}$ & $48.61(44.20)^{\mathrm{cd}}$ \\
\hline $27.78(31.80)^{\mathrm{de}}$ & $49.81(44.89)^{\mathrm{bc}}$ \\
\hline $31.21(33.97)^{\mathrm{ef}}$ & $40.00(39.23)^{\mathrm{fg}}$ \\
\hline $30.10(33.25)^{\mathrm{ef}}$ & $43.79(41.43)^{\mathrm{ef}}$ \\
\hline $30.79(33.69)^{\mathrm{ef}}$ & $44.14(41.63)^{\mathrm{def}}$ \\
\hline $33.33(35.26)^{\mathrm{f}}$ & $39.88(39.16)^{\mathrm{fg}}$ \\
\hline $48.33(54.53)^{\mathrm{g}}$ & $30.67(33.62)^{\mathrm{g}}$ \\
\hline 3.12 & 2.71 \\
\hline
\end{tabular}

$* \mathrm{RFD}=100 \%$ Recommended NPK dose; $100 \%$ recommended P and K applied in all treatments including control.

* Mean of three replications: Figures in Parenthesis are angular transformed values. 
Effect of recommended fertilizer doses (RFD), FYM and vermicompost application on wilt/root rot complex of chilli

The application of FYM or vermicompost to soil significantly reduced wilt/root rot incidence as well as improved chilli fruit production as compared to untreated check (Table 3). The minimum wilt/root rot incidence $(20.83 \%)$ was observed in the treatment wherein FYM @ 40 q/ha + RFD was applied which was at par with vermicompost $20 \mathrm{q} / \mathrm{ha}+\mathrm{RFD}(21.0 \%)$. The split doses of nitrogen also reduced the wilt/root rot incidence $(30.1-33.3 \%)$ in comparison to control (48.3\%). Maximum yield $(56.0 \mathrm{q} / \mathrm{ha})$ was observed in treatment wherein FYM 40 q/ha was applied which was followed by treatment combination of vermicompost $20 \mathrm{q} / \mathrm{ha}+\operatorname{RFD}(55.1 \mathrm{q} / \mathrm{ha})$, vermicompost @ 15 q/ha (53.9 q/ha) and FYM @ $30 \mathrm{q} / \mathrm{ha}(52.7 \mathrm{q} / \mathrm{ha})$ in comparison to $30.7 \mathrm{q} / \mathrm{ha}$ in untreated control. The split dose of nitrogen application (40:40:40) + FYM @ $20 \mathrm{q} / \mathrm{ha}$ also showed enhanced fruit yield (44.1 q/ha) in comparison to check (30.7 $\mathrm{q} / \mathrm{ha}$ ). While working on Capsicum annum $\mathrm{cv}$. Pusa Jawala (Saba Iqbal et al., 2013) observed that highest growth rates and plant yields are obtained by combined application of ammonium and nitrate fertilizers in comparison to their individual application. Aujla et al., 2007 reported that with increase in levels of $\mathrm{N}$ from $90-150 \mathrm{~kg} \mathrm{ha}^{-1}$ fresh fruit yield increases from 48.7- $85.4 \mathrm{t} \mathrm{ha}^{-1}$. Previous studies (Arancon et al., 2006; Bachman and Metzger, 2008) also revealed that vermicompost increases the number of fruits/ plant, fruit weight and total fruit yield of tomato. The above results are in agreement with Hussain et al., (2006) who reported that optimum increased application of nitrogen increased the asparagus root number and weight. Our findings are in agreement with Pal et al., (2003) reported that eggplant fruit yield increases with increase in $\mathrm{N}$ up to 187.5 $\mathrm{kg} \mathrm{N} \mathrm{ha}{ }^{-1}$. The beneficial effects of fertilizer on wilt incidence and yield parameter was also reported on chilli by Naeem et al., (2002), Chauhan et al., (2005), Khurana et al., (2006).

\section{References}

Alam MN, Jahan MS, Ali MK, Ashraf MA and Islam MA 2007. Effect of vermicompost and chemical fertilizers onn growth, yield and yield components of potato in barian soils of Bangladesh. Journal of Applied Sciences, 3(12): 1879-1888.

Anonymous 2010. Report from Government of Jammu and Kashmir, Directorate of Agriculture, Srinagar, Jammu \& Kashmir, India.

Anonymous 2013. Production and area under chillies and peppers dry in india for the year 2011. Food and Agriculture Organisation (FAO), Rome, Italy.

Arancon NQ, Edwards CA and Bierman P 2006. Influencs of vermicompost on field strawberries: effects on soil microbial and chemical properties. Bioresource Technology, 97: 831-834.

Aujla MS, Thind HS and Buttar GS 2007. Fruit yield and water use efficiency of eggplant (Solanum melongema L) as influenced by different quantities of nitrogen and water applied through drip and furrow irrigation. Scientia Horticulture, 112: 142-148.

Bagri RK, Choudhary SL, Rai PK 2004. Management of fruit rot of chilli with different plant products. Indian Phytopathol, 5, 107-109.

Bechman GR and Metzger JD 2008. Growth of bedding plants in commercial potting substrate amended with vermicompost. Bioresource Technology, 99: 31553161.

Bhardwaj U and Gautum HR 2004. Mulching 
with transparent polythene and root dip in fungicides for the management of collar and root rot of strawberry. Indian Phytopath, 57: 48-52.

Chauhan VL, Singh RV, Raghav M 2005. Optimum nitrogen and phosphorus fertilization in hybrid capsicum. Vegetable Science, 32, pp 200-202.

Dasgupta, M.K. 1988. Principles of Plant Pathology. Allied Publishers Pvt. Ltd., Banglore, p. 1140.

Gopinath K, Radhakrishnan NV and Jayaraj J 2006. Effect of propiconazole and difenoconazole on the con troll of anthracnose of chilli fruits caused by Colletotrichum capsici. Crop Protection, 25: 1024-1033.

Hussain A, Fouzia Amin, Rab A and Sajid M 2006. Effect of nitrogen on the growth and yield of asparagus (Asparagus officinalis). Journal of Agricultural and Biological Sciences, 2(1): 41-47.

Johnson A and Booth C 1983. The Plant Pathologists Pocket Book ( $2^{\text {nd }}$ ed.) Commonwealth Agricultural Bureaux, Slough, UK.

Khurana DS, Rupinder S, Sidhu AS and Ranjodh S 2006. Effect of different levels of nitrogen in split doses on growth and yield of chilli. Indian Journal of Horticulture, 63, pp 467-469.

Madhav Bindu and Bhattiprolu SL 2011. Integrated disease management of dry root rot of chilli incited by Sclerotium rolfsi. Inten. J. of Plant, Animal and Environmental Science. 2(1): 31-37.

Mamta Joshi, Rashmi Srivastava, Sharma AK and Anil Prakash 2012. Screening of resistance varities and antagonistic Fusarium oxysporum for biocontrol of Fusarium wilt of chilli. $J \mathrm{Pl}$ Pathol Microbiol., 3: 285-311.

McGee DC 1992. Epidemiological approach to disease management through seed technology. Ann Rev Phytopath., 45: 417-420.
Muthukrishnan CR, Thangraraj at, Chatterjee $\mathrm{R}$ and Maity T K 2002. Capsicum and chilli, In: T.K. Bose, J. Kabir, T.K. Maity, V.A. Pathasarthy \& M.G. Som (Eds,) Vegetable Crops. Pp 204-261. Naya Porkash, Kolkata, India.

Muthukumar A, Eswarana A, Nakkeeranb S and Sangeethaa G 2010. Efficacy of plant extracts and biocontrol agents against Pythium aphanidermatum inciting chilli damping-off. Crop Protection, 29: 1483-1488.

Naeem M, Muhammad I, Khan J, Nabi G, Muhammad N and Badshah H 2002. Influence of various levels of nitrogen and phosphorus on the growth and yield of chilli (Capsicum annum L). Asian journal of Plant Sciences, 5: 599-601.

Najar AG and Ahmad M 2012. Spatial distribution of chilli wilt causing pathogens in Kashmir. SKUAST J Res, 14: 54-58.

Nel B, Steinberg C, Labuschagne N and Viljoen A 2007. Evaluation of fungicides and sterilants for potential application in the management of Fusarium wilt of banana. Crop Ptotection 26: 695-705.

Nelson, P., Toussoun, T., Marasas, W. 1983. Fusarium species. An Illustrated Manual for Identification. The Pennsylvania State University Press, University Park, Pennsylvania, USA, p. 193.

Pal S, Saimbhi MS and Bal SS 2002. Effect of nitrogen and phosphorus levels on growth and yield of brinjal hybrid (Solanum melongema L). Veg. Sci, 29: 90-91.

Premsekhar C and Rajashree V 2009. Influence of organic manures on growth, yield and quality of okra. American Eurasian Journal of Sustainable Agriculture, 3(1): 120-121

Saba Iqbal, Inam A, Inam A, Tak HA 2013. Stimulation of growth, physiology and 
yield of Capsicum annum cv. Pusa Jawala by integration of nitrogenous fertilizers and waste water. Inten J Env. Sci., 5(3): 1727-1736.

Saini AK, Indu Jalali and Vijay P 2005. Ecofriendly management of Fusarium wilt and root knot nematode complex in tomato. J. Myco. Pl. Pathol. 2(35): 2025.

Sharma PN, Kour M, Sharma OP, Sharma P and Pathania A 2005. Morphological, pathological and molecular variability in Colletotrichum capsici, the cause of fruit rot of chillies in the subtropical region of North-western India. $J$ Phytopathol., 153, 232-237.

Sinha RJ, Valani D, Chauhan K and Agarwal S 2010. Embarking on a second green revolution for sustainable agriculture by vermicompost biotechnology using earthworms: reviving the dreams of Sir Charles Darwin, Agriculture Sciences, 2(7): 113-128.

Sneh, B., Burpee, L. and Ogoshi, A. 1998. Identification of Rhizoctonia species. American Phytopathological Society, Press, St. Paul, Minnesota, USA, p. 129.

Stevens C, Khan VA, Kabana R, Ploper LD, Bakkan PA, Collins DJ, Brown JE, Wilson MA and Igmedge ECK 2003. Integration of soil solarization, chemical, biological and cultural control for the management of soil borne diseases of vegetables. Pl Soil., 253: 493-496.
Suneel A and Gautum HR 2006. Use of soil solarization, biocontrol agents, fungicides corn dip and soil amendments for management of Fusarium wilt pathogen of gladiolus. $J$. Myco. Pl. Pathol., 2(34): 201-204.

Tarekegn G, Sakhuja PK, Swart WJ and Tomado $\mathrm{T}$ 2007. Integrated management of groundnut root rot using seed quality and fungicide seed treatment. Int. J. Pest Manage. 53: 5357.

Uddin MK and Khalequzzaman KM 2003. Yield and yield component of winter chilli (Capsicum annum L) as affected by different levels of nitrogen and boron. Pakistan Journal of Biological Sciences, 6(6): pp 605-609.

Vatchev TD 2007. First report of Fusarium root and stem rot of greenhouse cucumber caused by Fusarium oxysporum f.sp. radicis-cucumerinum in Bulgaria. Bulg J. Agri. Sci., 13: 152153.

Yelmame MG, Mehta BP, Deshmukh AJ and Patil VA (2010). Evaluation of some organic extracts in in vitro to control Fusarium solani causing chilli wilt. Intern. J Pharmo Bio-Sci., 7: 122-126.

Zagade SN, Deshpande GD, Gawade BD, Atnoorkar AA and Pawar SV (2012). Biocontrol agents and fungicides for management of damping-off in chilli. World J. Agri. Sci., 8(6): 590-597.

\section{How to cite this article:}

Waseem Ali Dar, Mir Gh. Hassan, Pervaiz Ahmad Sheikh, Baby Summuna and Shabir Ahmad Ganaie. 2018. Integrated Disease Management Capsule for Wilt/Root Rot Complex of Chili. Int.J.Curr.Microbiol.App.Sci. 7(01): 1253-1261. doi: https://doi.org/10.20546/ijcmas.2018.701.152 